\title{
Литолого-структурная характеристика
} карбонатных отложений фаменско-турнейского яруса нефтяных месторождений юга Пермского Прикамья

\section{В.И. Луппов}

Пермский государственный национальный исследовательский университет, 614990, Пермь, ул. Генкеля, 8. E-mail: luppov@psu.ru

(Статья поступила в редакичюю 2 ноября 2015 г.)

\begin{abstract}
Представлено распределение литологических разностей карбонатных пород месторождений юга Пермского Прикамья. Установлено, что турнейские отложения сложены преимущественно сгустково-водорослевыми известняками. Лучшими фильтрационно-ёмкостными свойствами $($ Кп $=12-15 \%$, Кпр $=(100-$ $200) \cdot 10^{-3}$ мкм $\left.^{2}\right)$ характеризуются водорослевые, а худшими $($ Кп $=8-10 \%$, Кпр = $(0,1-2) \cdot 10^{-3}$ мкм $\left.^{2}\right)$ - сгустковые известняки. Результаты исследований рекомендуются к использованию при геологическом и гидродинамическом моделировании нефтяных залежей.

Ключевые слова: карбонатные породы, литология, трещиноватость, кавернозность, известняк.
\end{abstract}

DOI: $10.17072 /$ psu.geol.31.83

Анализ литологических особенностей проведен по данным микроописаний на примере 1053 образцов 5 месторождений (Кудрявцевского, Аптугайского, Москудьинского, Солдатовского, Софьинского), из которых на турнейские отложения приходится 821 образец, на фаменские - 232 образца. По литологоструктурным особенностям были выделены шесть литотипов: известняки комковатые (Икм), сгустковые (Исг), детритовые (Ид), водорослевые (Ив), фораминиферовые (Иф) и доломиты (Д). Встречаемость их по совокупности всех поднятий приведена в табл. 1, а в пределах отдельных месторождений (поднятий) - в табл. 2.

Турнейские отложения (пласты $\mathrm{T}_{1}-\mathrm{T}_{3}$ ) сложены преимущественно водорослевыми известняками $(34.8 \%)$ и сгустковыми $(24.7 \%)$. В значительном количестве присутствуют также комковатые известняки $(16.2 \%)$ и детритовые $(16,6 \%)$, доля всех остальных типов пород не превышает $8 \%$. Следовательно, турнейские отложения образованы преимущественно сгусткововодорослевыми известняками.

Плотные части разрезов (пласты $\mathrm{T}_{1}-\mathrm{T}_{3}$ ) по литологическому составу отличаются от пористых. Среди плотных над водорослевыми незначительно преобладают сгустковые известняки $(28.7 \%)$, а среди пористых, наоборот, - водорослевые (39.0\%). Более резкое различие отмечается между нефте- и водонасыщенными частями пластов [4]. Пористые породы нефтенасыщенных частей пластов сложены в большей части водорослевыми известняками (43.9\%), а плотные в равном соотношении водорослевыми $(30,3 \%)$ и сгустковыми (29.9\%).

Кроме того, среди плотных существенно увеличивается доля доломитов до $7 \%$ против $0.5 \%$ в пористых. Особенно сильно по составу отличаются 
Таблица 1. Средняя встречаемость типов карбонатных пород по 5 месторождениям

\begin{tabular}{|c|c|c|c|c|c|c|c|c|c|c|c|c|c|c|}
\hline \multirow{3}{*}{$\begin{array}{c}\text { Литоти- } \\
\text { пы по- } \\
\text { род }\end{array}$} & \multicolumn{7}{|c|}{ Отложения $\mathrm{T}_{1}-\mathrm{T}_{3}$} & \multirow{2}{*}{\multicolumn{3}{|c|}{$\begin{array}{c}\text { Отложения фм } \\
\mathrm{H}+\mathrm{B} / \mathrm{\varphi}\end{array}$}} & \multicolumn{2}{|c|}{$\begin{array}{c}\text { Каверноз- } \\
\text { ные }\end{array}$} & \multicolumn{2}{|c|}{$\begin{array}{l}\text { Tрещино- } \\
\text { ватые }\end{array}$} \\
\hline & \multicolumn{2}{|c|}{ Н/ч пласта } & \multicolumn{2}{|c|}{ В/ч пласта } & \multicolumn{2}{|c|}{ H+в/ч пласта } & \multirow{2}{*}{\begin{tabular}{|c}
$\mathrm{H}+\mathrm{B} /$ \\
ч
\end{tabular}} & & & & \multirow[b]{2}{*}{$\begin{array}{l}\text { отл. } \\
\mathrm{T}_{1}-\mathrm{T}_{3}\end{array}$} & \multirow[b]{2}{*}{$\begin{array}{c}\text { отл. } \\
\text { фм }\end{array}$} & \multirow[b]{2}{*}{$\begin{array}{c}\text { отл. } \\
\mathrm{T}_{1}-\mathrm{T}_{3}\end{array}$} & \multirow[b]{2}{*}{$\begin{array}{c}\text { отл. } \\
\text { фм }\end{array}$} \\
\hline & $\begin{array}{l}\text { по- } \\
\text { ри- } \\
\text { стая }\end{array}$ & $\begin{array}{l}\text { плот- } \\
\text { ная }\end{array}$ & $\begin{array}{l}\text { по- } \\
\text { ри- } \\
\text { стая }\end{array}$ & $\begin{array}{c}\text { плот- } \\
\text { ная }\end{array}$ & $\begin{array}{l}\text { по- } \\
\text { ри- } \\
\text { стая } \\
\end{array}$ & $\begin{array}{l}\text { плот- } \\
\text { ная }\end{array}$ & & \begin{tabular}{|l} 
по- \\
ри- \\
стые \\
\end{tabular} & $\begin{array}{c}\text { плот- } \\
\text { ные }\end{array}$ & $\begin{array}{c}\text { в } \\
\text { це- } \\
\text { лом } \\
\end{array}$ & & & & \\
\hline $\begin{array}{l}\text { Комко- } \\
\text { ватые }\end{array}$ & $\begin{array}{l}17,5 / \\
77\end{array}$ & $\begin{array}{l}22,4 / \\
95\end{array}$ & $8.3 / 9$ & $2.8 / 2$ & $\begin{array}{l}15.7 / \\
86\end{array}$ & $17.3 / 47$ & $\begin{array}{l}16.2 / \\
13.3\end{array}$ & $\begin{array}{l}47.8 / \\
55\end{array}$ & $\begin{array}{l}15.4 / \\
18\end{array}$ & $\begin{array}{l}31.5 / \\
73\end{array}$ & \begin{tabular}{|l|}
$25.9 /$ \\
37
\end{tabular} & $\begin{array}{l}18.6 / \\
8\end{array}$ & $\begin{array}{l}23.2 / \\
29\end{array}$ & $\begin{array}{l}34 / \\
17\end{array}$ \\
\hline $\begin{array}{l}\text { Сгуст- } \\
\text { ковые }\end{array}$ & $\begin{array}{l}20.9 / \\
92\end{array}$ & $\begin{array}{l}29.9 / \\
60 \\
\end{array}$ & $\begin{array}{l}30.3 / \\
33 \\
\end{array}$ & $25.4 / 18$ & \begin{tabular}{|l|}
$22.8 /$ \\
125 \\
\end{tabular} & $28.7 / 78$ & \begin{tabular}{|l|}
$24.7 /$ \\
203 \\
\end{tabular} & \begin{tabular}{|l|}
$22.6 /$ \\
26
\end{tabular} & $41 / 48$ & $\begin{array}{l}30.2 / \\
70 \\
\end{array}$ & \begin{tabular}{|l|}
$11.2 /$ \\
16 \\
\end{tabular} & \begin{tabular}{|l|}
$30.7 /$ \\
13 \\
\end{tabular} & $\begin{array}{l}26.2 / \\
34 \\
\end{array}$ & \begin{tabular}{|l|}
$42 /$ \\
21 \\
\end{tabular} \\
\hline $\begin{array}{l}\text { Детри- } \\
\text { товые }\end{array}$ & $15 / 66$ & \begin{tabular}{|l}
$9.5 /$ \\
19 \\
\end{tabular} & $\begin{array}{l}28.4 / \\
31 \\
\end{array}$ & $28.2 / 20$ & \begin{tabular}{|l|}
$17.7 /$ \\
97 \\
\end{tabular} & $\mid 14.3 / 39$ & \begin{tabular}{|l|}
$16.6 /$ \\
136 \\
\end{tabular} & 7.8/9 & \begin{tabular}{|l|}
$14.5 /$ \\
17 \\
\end{tabular} & $\begin{array}{l}11.2 / \\
26\end{array}$ & $4.9 / 7$ & $6.9 / 3$ & $\begin{array}{l}8.5 / \\
11 \\
\end{array}$ & $4 / 2$ \\
\hline $\begin{array}{c}\text { Водо- } \\
\text { росле- } \\
\text { вые } \\
\end{array}$ & $\begin{array}{l}43.9 / \\
193\end{array}$ & $\begin{array}{l}30.3 / \\
61\end{array}$ & $\begin{array}{l}19.3 / \\
21\end{array}$ & 15.5/11 & $\begin{array}{l}39 / \\
214\end{array}$ & /72 & $\begin{array}{l}34.8 / \\
286\end{array}$ & $\begin{array}{l}19.1 / \\
22\end{array}$ & $\begin{array}{l}14.5 / \\
17\end{array}$ & $\begin{array}{l}16.8 / \\
39\end{array}$ & $\begin{array}{l}44.8 / \\
64\end{array}$ & $\begin{array}{l}16.2 / \\
7\end{array}$ & $\begin{array}{l}38.5 / \\
50\end{array}$ & $10 / 5$ \\
\hline \begin{tabular}{|c|} 
Доломи- \\
ты \\
\end{tabular} & $0.5 / 2$ & 7/14 & $0.9 / 1$ & 22.5/16 & $0.5 / 3$ & $11 / 30$ & $4 / 33$ & $2.6 / 3$ & \begin{tabular}{|l|}
$12.8 /$ \\
15 \\
\end{tabular} & \begin{tabular}{|l|}
$7.8 /$ \\
18 \\
\end{tabular} & $6.3 / 9$ & $\begin{array}{l}27.9 / \\
12 \\
\end{array}$ & $2.3 / 3$ & $8 / 4$ \\
\hline \begin{tabular}{|c|}
$\begin{array}{c}\text { Форами- } \\
\text { ниферо- } \\
\text { вые }\end{array}$ \\
\end{tabular} & $1.8 / 8$ & $0.5 / 1$ & $11 / 12$ & $2.8 / 2$ & $\begin{array}{l}3.6 / \\
20\end{array}$ & $1.1 / 3$ & $\begin{array}{l}2.8 / \\
2.3\end{array}$ & - & $1.7 / 2$ & $0.9 / 2$ & $4.9 / 7$ & - & $2.3 / 3$ & - \\
\hline Разные & $0.5 / 2$ & $0.5 / 1$ & $1.8 / 2$ & $2.8 / 2$ & $0.7 / 4$ & $1.1 / 3$ & $0.8 / 7$ & - & $0.9 / 1$ & - & $2.1 / 3$ & - & - & $2 / 1$ \\
\hline иТОГО & 440 & 201 & 109 & 71 & 549 & 272 & 821 & 115 & 118 & 232 & 143 & 43 & 130 & 50 \\
\hline
\end{tabular}

Примечание: числитель - \%, знаменатель - образцы, тире - отсутствие керна, н/ч - нефтенасыщенная часть пласта, в/ч - водонасыщенная часть пласта, Н+в/ч - нефтенасыщенная + водонасыщенная части пласта, $\mathrm{T}_{1}-\mathrm{T}_{3}-$ отложения турнейского яруса, фм - отложения фаменского яруса.

Таблица 2. Встречаемость литотипов карбонатных пород в конкретных месторождениях

\begin{tabular}{|c|c|c|c|c|c|c|c|c|c|}
\hline \multirow{2}{*}{\multicolumn{2}{|c|}{ Тип породы }} & \multicolumn{2}{|c|}{ Н/ч пласта } & \multicolumn{2}{|c|}{ В/ч пласта } & \multicolumn{2}{|c|}{ Кавернозные } & \multicolumn{2}{|c|}{ Трещиноватые } \\
\hline & & $\mathrm{T}_{1}-\mathrm{T}_{3}$ & $\phi м$ & $\mathrm{~T}_{1}-\mathrm{T}_{3}$ & $\phi м$ & $\mathrm{~T}_{1}-\mathrm{T}_{3}$ & фм & $\mathrm{T}_{1}-\mathrm{T}_{3}$ & фм \\
\hline \multicolumn{10}{|c|}{ Кудрявиевское месторождение } \\
\hline & & & & & & & & & \\
\hline \multirow{2}{*}{ Комковатые } & Пор. & $8.7 / 9$ & & & & & & $2.7 / 1$ & \\
\hline & Пл. & $1.9 / 2$ & & $3.3 / 1$ & & $14.3 / 2$ & & $2.7 / 1$ & \\
\hline \multirow{2}{*}{ Сгустковые } & Пор. & $11.8 / 12$ & & & & & & $2.7 / 1$ & \\
\hline & Пл. & $33.3 / 34$ & & $13.3 / 4$ & & $57.1 / 8$ & & $64.9 / 24$ & $100 / 4$ \\
\hline \multirow{2}{*}{ Детритовые } & Пор. & $11.8 / 12$ & & $3.3 / 1$ & & & $100 / 1$ & $2.7 / 1$ & \\
\hline & Пл. & $5.9 / 6$ & & $50 / 15$ & & $28.6 / 4$ & & $18.9 / 7$ & \\
\hline \multirow{2}{*}{ Водорослевые } & Пор. & $23.5 / 24$ & & & & & & $2.7 / 1$ & \\
\hline & Пл. & $3.9 / 4$ & & $30 / 9$ & & & & $2.7 / 1$ & \\
\hline ВСЕГО & & 102 & & 30 & & $10.6 / 14$ & $0.7 / 1$ & $28 / 37$ & $3 / 4$ \\
\hline \multicolumn{10}{|c|}{ Аптугайское месторождение } \\
\hline \multirow{2}{*}{ Комковатые } & Пор. & $9 / 16$ & & $11.1 / 2$ & & $6.9 / 5$ & & $4.7 / 3$ & \\
\hline & Пл. & $13.5 / 24$ & & & & $27.8 / 20$ & & $29.7 / 19$ & \\
\hline \multirow{2}{*}{ Сгустковые } & Пор. & $14 / 25$ & & $22.2 / 4$ & & $1.4 / 1$ & & & \\
\hline & Пл. & $4.5 / 8$ & & $50 / 9$ & & $2.8 / 2$ & & & \\
\hline \multirow{2}{*}{ Детритовые } & Пор. & $1.1 / 2$ & & & & & & & \\
\hline & Пл. & $2.8 / 5$ & & $5.6 / 1$ & & & & & \\
\hline
\end{tabular}




\section{Продолжение табл. 2}

\begin{tabular}{|c|c|c|c|c|c|c|c|c|c|}
\hline \multirow{2}{*}{\multicolumn{2}{|c|}{ Тип породы }} & \multicolumn{2}{|c|}{ Н/ч пласта } & \multicolumn{2}{|c|}{ В/ч пласта } & \multicolumn{2}{|c|}{ Кавернозные } & \multicolumn{2}{|c|}{ Трещиноватые } \\
\hline & & $\mathrm{T}_{1}-\mathrm{T}_{3}$ & фм & $\mathrm{T}_{1}-\mathrm{T}_{3}$ & фм & $\mathrm{T}_{1}-\mathrm{T}_{3}$ & фм & $\mathrm{T}_{1}-\mathrm{T}_{3}$ & фм \\
\hline \multirow{2}{*}{ Водорослевые } & Пор. & $18.5 / 33$ & & $11.1 / 2$ & & $5.6 / 4$ & & $3.1 / 2$ & \\
\hline & Пл. & $29.2 / 52$ & & & & $50 / 36$ & & $60.9 / 39$ & \\
\hline \multirow{2}{*}{ Доломиты } & Пор. & $1.1 / 2$ & & & & $1.4 / 1$ & & & \\
\hline & Пл. & $6.2 / 11$ & & & & $4.2 / 3$ & & $1.6 / 1$ & \\
\hline ВСЕГО & & 178 & & 18 & & 72 & & 64 & \\
\hline \multicolumn{10}{|c|}{ Москудьинское месторождение } \\
\hline \multirow{2}{*}{ Комковатые } & Пор. & $30.3 / 27$ & & $10.6 / 5$ & & $19 / 4$ & & $27.6 / 2$ & \\
\hline & Пл. & $3.4 / 3$ & & & & & & $14.3 / 1$ & \\
\hline \multirow{2}{*}{ Сгустковые } & Пор. & $19.1 / 17$ & & $10.6 / 5$ & & $9.5 / 2$ & & & \\
\hline & Пл. & $1.1 / 1$ & & $2.1 / 1$ & & $4.7 / 1$ & & & \\
\hline \multirow{2}{*}{ Детритовые } & Пор. & $33.7 / 30$ & & $21.3 / 10$ & & & & $14.3 / 1$ & \\
\hline & Пл. & $2.2 / 2$ & & $8.5 / 4$ & & $9.5 / 2$ & & $14.3 / 1$ & \\
\hline \multirow[b]{2}{*}{ Водорослевые } & Пор. & & & $6.4 / 3$ & & & & & \\
\hline & Пл. & & & $2.1 / 1$ & & & & & \\
\hline \multirow{2}{*}{ Доломиты } & Пор. & & & $2.1 / 1$ & & & & & \\
\hline & Пл. & $1.1 / 1$ & & $25.5 / 12$ & & $23.8 / 5$ & & & \\
\hline \multirow{2}{*}{$\begin{array}{c}\text { Фораминиферо- } \\
\text { вые }\end{array}$} & Пор. & $7.9 / 7$ & & $4.3 / 2$ & & $14.3 / 3$ & & $28.6 / 2$ & \\
\hline & Пл. & & & $2.1 / 1$ & & $4.8 / 1$ & & & \\
\hline \multirow{2}{*}{ Другие } & Пор. & & & & & & & & \\
\hline & Пл. & $1.1 / 1$ & & $4.3 / 2$ & & $14.3 / 3$ & & & \\
\hline ВСЕГО & & 89 & & 47 & & 21 & & 7 & \\
\hline \multicolumn{10}{|c|}{ Софьинское месторождение } \\
\hline \multirow{2}{*}{ Комковатые } & Пор. & $6.0 / 13$ & $28.4 / 48$ & & & $3.7 / 1$ & $20.7 / 6$ & $11.8 / 2$ & $\begin{array}{c}31.6 / \\
12\end{array}$ \\
\hline & Пл. & $4.5 / 10$ & $6.8 / 15$ & $0.5 / 1$ & & & $0.5 / 1$ & & $0.9 / 2$ \\
\hline \multirow{2}{*}{ Сгустковые } & Пор. & $9 / 20$ & $8.1 / 18$ & $2.3 / 5$ & $0.5 / 1$ & $0.9 / 2$ & $0.9 / 2$ & & $2.7 / 6$ \\
\hline & Пл. & $7.2 / 16$ & $12.2 / 27$ & $0.9 / 2$ & $0.5 / 1$ & & $1.4 / 3$ & $4.1 / 9$ & $4.5 / 10$ \\
\hline \multirow{2}{*}{ Детритовые } & Пор. & $9.5 / 21$ & \begin{tabular}{|c|}
$3.6 / 8$ \\
\end{tabular} & $2.7 / 6$ & & & & & \\
\hline & Пл. & $1.8 / 4$ & $5.4 / 12$ & & & $0.5 / 1$ & $0.9 / 2$ & & $0.5 / 1$ \\
\hline Волипогерге & Пор. & $59.3 / 131$ & $8.1 / 18$ & $6.3 / 14$ & $0.9 / 2$ & $10.4 / 23$ & $1.8 / 4$ & $2.3 / 5$ & $0.5 / 1$ \\
\hline Водорослевые & Пл. & $1.8 / 4$ & $5.4 / 12$ & $0.5 / 1$ & $0.5 / 1$ & & $0.5 / 1$ & $0.5 / 1$ & $1.4 / 3$ \\
\hline$\pi$ & Пор. & & $0.9 / 2$ & & $0.5 / 1$ & & $0.5 / 1$ & & \\
\hline Доломиты & Пл. & & $3.6 / 8$ & $1.8 / 4$ & $1.4 / 3$ & & $3.6 / 8$ & & $0.9 / 2$ \\
\hline Обломоншен & Пор. & $0.9 / 2$ & & & & & & & \\
\hline Ооломочные & Пл. & & $0.5 / 1$ & & & & $0.5 / 1$ & & $0.5 / 1$ \\
\hline To & Пор. & & & & & & & & \\
\hline Фораминиферовые & Пл. & & & $0.5 / 1$ & & & & & \\
\hline ВСЕГО & & 221 & 169 & 34 & 9 & 27 & 29 & 17 & 38 \\
\hline & & & олдатов & кое мест & рожде & & & & \\
\hline Комсоватие & Пор. & $24 / 12$ & $12.2 / 5$ & $3.9 / 2$ & $12 / 2$ & $33.3 / 3$ & & & \\
\hline Комковатые & Пл. & $12 / 6$ & $29.3 / 12$ & & $5.9 / 1$ & $2.2 / 2$ & $7.1 / 1$ & $16.7 / 1$ & $37.5 / 3$ \\
\hline Cгустновие & Пор. & $36 / 18$ & $9.8 / 4$ & $37.3 / 19$ & $17.6 / 3$ & & $50 / 7$ & & \\
\hline Сгустковые & Пл. & $2 / 1$ & $24.4 / 10$ & $3.9 / 2$ & $23.5 / 4$ & & $7.1 / 1$ & & $12.5 / 1$ \\
\hline Петпитовие & Пор. & $2 / 1$ & $2.4 / 1$ & $27.5 / 14$ & & & & & \\
\hline детритовые & Пл. & 4.2 & $12.2 / 5$ & & & & & $16.7 / 1$ & $12.5 / 1$ \\
\hline Вопопосперие & Пор. & $10 / 5$ & & $4 / 2$ & $11.8 / 2$ & $11.1 / 1$ & $14.3 / 2$ & $16.7 / 1$ & \\
\hline Водорослевые & Пл. & $2 / 1$ & $7.3 / 3$ & & $5.9 / 1$ & & & & $12.5 / 1$ \\
\hline Пөген & Пор. & & & & & & & & \\
\hline Доломиты & Пл. & $4 / 2$ & & & $23.5 / 4$ & & $21.4 / 3$ & $33.3 / 2$ & $25 / 2$ \\
\hline
\end{tabular}


Окончание табл. 2

\begin{tabular}{|c|c|c|c|c|c|c|c|c|c|}
\hline \multicolumn{2}{|c|}{ Тип породы } & \multicolumn{2}{c|}{$\mathrm{H} /$ ч пласта } & \multicolumn{2}{c|}{$\mathrm{B} /$ пласта } & \multicolumn{2}{c|}{ Кавернозные } & \multicolumn{2}{c|}{ Трещиноватые } \\
\cline { 2 - 11 } Обломочные & Пор. & & & $3.9 / 2$ & & & & & \\
\cline { 2 - 10 } & Пл. & & & & & & & & \\
\hline \multirow{2}{*}{ Фораминиферовые } & Пор. & $2 / 1$ & & $19.6 / 10$ & & $33.3 / 3$ & & $16.7 / 1$ & \\
\cline { 2 - 11 } & Пл. & $2 / 1$ & $2.4 / 1$ & & & & & & \\
\hline \multirow{2}{*}{ ВСЕГО } & & 50 & 41 & 51 & 17 & 9 & 14 & 6 & 8 \\
\hline \multirow{2}{*}{ ИТОГО } & Пор. & & & & & $9.7 / 53$ & $19.3 / 23$ & $4.4 / 24$ & $16.0 / 19$ \\
\cline { 2 - 10 } & Пл. & & & & & $33.2 / 90$ & $17.4 / 21$ & $39.9 / 18$ & $25.6 / 31$ \\
\hline
\end{tabular}

Примечание: числитель - \%, знаменатель - образцы, пор. - пористые, пл. - плотные, н/ч - нефтенасыщенная часть пласта, в/ч - водонасыщенная часть пласта, $\mathrm{T}_{1}-\mathrm{T}_{3}-$ отложения турнейского яруса, фм отложения фаменского яруса.

водонасыщенные части пластов. Они представлены главным образом сгустковыми $(25.4-30,3 \%)$ и детритовыми $(28.2$ - 28.4\%) известняками как в пористых, так и в плотных частях разреза. Среди плотных пород в значительном количестве встречаются доломиты (22.5\%).

Основное отличие фаменских отложений состоит в том, что в их эффективных частях преобладают комковатые известняки (47.8\%), а в плотной - сгустковые (41\%). В плотной части, как и в турнейских отложениях, значительно больше доломитов (12.8 против 2.6\%).

В заключение следует подчеркнуть, что в целом турнейские отложения сложены сгустково-водорослевыми известняками, а фаменские - сгустковокомковатыми. В плотной части этих отложений характерно увеличение количества доломитов. В сравнении с аналогичными отложениями Соликамской депрессии в пределах Башкирского свода они сложены теми же самыми литотипами карбонатных пород. Однако в Соликамской депрессии по составу они более однородные, т.к. наблюдается резкое преобладание сгустково-комковатых известняков $(75 \%)$, а доля всех остальных, как и доломитов, второстепенная [7].

Встречаемость литотипов пород в пределах конкретных месторождений не всегда подчиняется общей закономерности, описанной выше для пластов в целом (табл.2). Так, среди турнейских отложе- ний Москудьинского месторождения преобладают детритовые и комковатые известняки, а на Софьинском - комковатосгустковые. Кроме этого, на этих месторождениях отмечается повышенное количество доломитов в водонасыщенных частях $(23.3-25.5 \%)$.

Кавернозность и трещиноватость пород. По макроописаниям керна в турнейско-фаменских отложениях отмечаются кавернозность, а также иногда значительная микро- и макротрещиноватость как, например, на Аптугайском месторождении. Относительно встречаемости их в различных литологических типах пород можно отметить следующее (табл. 1): в турнейских отложениях кавернозными являются водорослевые известняки (44.8\%), чаще всего встречающиеся, и в подчиненном количестве - комковатые (25.9\%), в фаменских - преимущественно сгустковые $(30.7 \%)$, хотя преобладают в них преимущественно комковатые, и доломиты $(27.9 \%)$.

Трещиноватость пород в турнейских отложениях в первую очередь свойственна водорослевым известнякам $(38.5 \%)$ и сгустковым (26.2\%), а в фаменских сгустковым (42\%) и комковатым (34\%). Следует подчеркнуть несколько меньшую склонность пористых пород к трещинообразованию в сравнении с кавернозностью.

Согласно табл.2, можно говорить о сильном колебании количества кавернозных пород (до 57\% на Кудрявцевском ме- 
сторождении) среди отдельных литологических типов в пределах конкретных месторождений и о преимущественной приуроченности их к плотным частям разрезов. Именно это можно сказать относительно трещиноватости. В плотных породах на трещиноватые разности приходится иногда до 60.9 - 64.9\% (Аптугайское и Кудрявцевское месторождения), а в пористых не более 27.6 - 28.6\% (Москудьинское месторождение). В турнейских отложениях в среднем трещиноватых пород среди пористых 4.4\%, а среди плотных $39.9 \%$. В фаменских отложениях среди пористых и плотных пород на трещиноватые приходится соответственно 16.0 и $25.6 \%$. Что касается кавернозности, то в плотных породах турнейских отложений её доля также высока - 33.2 против 9.7\% в пористых. В фаменских отложениях кавернозные породы среди плотных и пористых встречаются примерно в одинаковом количестве, соответственно 17.4 и 19,3\%.

Отдельно по каждому месторождению и пласту в целом встречаемость трещиноватых, кавернозных, а также одновременно трещиноватых и кавернозных пород выше ВНК (по данным 836 образцов керна) представлена в табл.3. Полученные результаты также подтверждают крайнюю неравномерность развития трещиноватости и кавернозности [10]. Это проявляется в том, что степень интенсивности их неодинакова как на отдельных месторождениях, так и в породах разновозрастных отложений [3]. Например, трещиноватость характерна для турнейских отложений Кудрявцевского $(51,5 \quad-\quad 90 \%)$ и Аптугайского $(57,1 \%)$ месторождений и фаменских - на Кудрявцевском (66,7\%). В целом она достаточно высокая и больше всего свойственна пл. $\mathrm{T}_{2}(49,1 \%)$ и $\mathrm{T}_{3}$ $(37,3 \%)$. Именно это можно сказать и о проявлении кавернозности. Но в целом по кавернозности выделяется пл. $\mathrm{T}_{2}$, где она достигает $43,1 \%$. Породы одновременно кавернозные и трещиноватые встречаются значительно реже. В данном случае резко выделяются пл. $\mathrm{T}_{2}$ на Аптугайском месторождении, где на них приходится значительная доля $(55,6 \%)$, и пл. $\mathrm{T}_{3}$ на Кудрявцевском, где таких пород 40\%.

Резюмируя полученные данные, нужно подчеркнуть, что трещиноватость и кавернозность плотных турнейских отложений выше в сравнении с подобными отложениями фаменских, причем выделяется среди них по этим признакам пл. $\mathrm{T}_{2}$. В пористых породах наблюдается обратное соотношение, более трещиноватыми и кавернозными являются фаменские отложения.

Установленные особенности могут свидетельствовать: во-первых, деформационным напряжениям в большей степени подвержены турнейские отложения [2,9]; во-вторых, наиболее интенсивно трещиноватость проявлялась в плотных породах и особенно в турнейских отложениях; втретьих, системы трещиноватости фаменских и турнейских отложений различаются, в первом случае - она была совершенней гидродинамически, что обеспечило более активное кавернообразование в фаменских отложениях [8].

Особенность проявления трещиноватости состоит в том, что её максимальные значения тяготеют к центральным зонам купольных поднятий. Примером могут служить скв. 19 на Кудрявцевском куполе, где на трещиноватые породы приходится от 66 до 90\%, скв. 42 на ЗападноКораблевском (100\%), скв. 4 на Аптугайском (до 94,7\%), скв. 93 на Солдатовском $(31,9 \%)$, скв. 63 на Софьинском (до $72,7 \%$ ). В меньшей степени трещиноватые породы развиты на крыльях поднятий: в скв. 40 и 51 Кудрявцевского месторождения до 20\%, в скв. 39 и 48 Солдатовского - соответственно до 45,5 и $20 \%$.

Минимальная встречаемость или полное отсутствие трещиноватых пород наблюдается в мульдообразных участках между куполами: в скв. 138 ЗападноКораблевского поднятия - $13,3 \%$, в скв. 156 Аптугайского - 0,0\%, в скв. 37 и 38 Солдатовского соответственно 4,8 и $0,0 \%$. Отмеченную приуроченность 
Таблица 3. Встречаемость трещчиноватых и кавернозных пород на различных структурах

\begin{tabular}{|c|c|c|c|c|c|c|c|c|c|c|c|c|c|}
\hline \multirow[b]{2}{*}{$\begin{array}{l}\text { Месторожде- } \\
\text { ние, поднятие }\end{array}$} & \multicolumn{4}{|c|}{ Трещиноватые } & \multicolumn{4}{|c|}{ Кавернозные } & \multicolumn{4}{|c|}{ Кавернозно-трещиноватые } & \multirow{2}{*}{$\begin{array}{l}\text { скв. / } \\
\text { обра- } \\
\text { зец }\end{array}$} \\
\hline & Пл. $\mathrm{T}_{1}$ & $\begin{array}{l}\text { Пл. } \\
\mathrm{T}_{2}\end{array}$ & $\begin{array}{c}\text { Пл. } \\
\mathrm{T}_{3}\end{array}$ & $\begin{array}{l}\text { Пл. } \\
\text { фм }\end{array}$ & $\begin{array}{c}\text { Пл. } \\
\mathrm{T}_{1}\end{array}$ & $\begin{array}{l}\text { Пл. } \\
\mathrm{T}_{2} \\
\end{array}$ & $\begin{array}{c}\text { Пл. } \\
\mathrm{T}_{3}\end{array}$ & $\begin{array}{l}\text { Пл. } \\
\text { фм }\end{array}$ & Пл. $\mathrm{T}_{1}$ & $\begin{array}{c}\text { Пл. } \\
\mathrm{T}_{2}\end{array}$ & Пл. $\mathrm{T}_{3}$ & $\begin{array}{l}\text { Пл. } \\
\text { фм }\end{array}$ & \\
\hline $\begin{array}{r}\text { удрявце } \\
\text { купо. }\end{array}$ & $\begin{array}{c}9.6 / 5 / \\
52\end{array}$ & $\begin{array}{l}51.5 / \\
17 / 93\end{array}$ & $\begin{array}{c}90 / 9 / \\
10\end{array}$ & $\begin{array}{c}66.7 / 4 \\
/ 6\end{array}$ & $\begin{array}{c}0.0 / 0 / \\
52\end{array}$ & $\begin{array}{c}18.2 / 6 \\
/ 33\end{array}$ & \begin{tabular}{|c|}
$40 / 4 /$ \\
10
\end{tabular} & $\begin{array}{c}16.7 / 1 \\
/ 6\end{array}$ & $0 / 0 / 52$ & $\begin{array}{c}18.2 / 6 \\
133\end{array}$ & $\begin{array}{c}40 / 4 / \\
10\end{array}$ & $0 / 0 / 6$ & $7 / 101$ \\
\hline $\begin{array}{l}\text { Зап. K } \\
\text { ское г }\end{array}$ & $\begin{array}{l}7.1 / 2 / \\
28\end{array}$ & - & $\begin{array}{c}100 / 3 \\
/ 3\end{array}$ & - & $\begin{array}{c}2.7 / 1 / \\
37\end{array}$ & - & $\begin{array}{c}100 / \\
3 / 3\end{array}$ & - & $\begin{array}{c}2.7 / 1 / \\
37\end{array}$ & - & $10 / 3 / 3$ & - & $4 / 31$ \\
\hline & $\begin{array}{l}14.6 / \\
13 / 89\end{array}$ & $\begin{array}{l}57.1 / \\
36 / 63\end{array}$ & $0 / 0 / 3$ & - & $\begin{array}{c}4.5 / 4 / \\
89\end{array}$ & $\begin{array}{l}58.7 / \\
37 / 63\end{array}$ & $/ 0 / 3$ & - & $\begin{array}{c}1.1 / 1 / \\
89\end{array}$ & \begin{tabular}{|l|}
$55.6 /$ \\
$35 / 63$
\end{tabular} & $0 / 3$ & - & 55 \\
\hline oe & $\begin{array}{c}15 / 3 / \\
20\end{array}$ & $\begin{array}{c}20 / 4 / \\
20\end{array}$ & - & - & $\begin{array}{c}30 / 6 / \\
20\end{array}$ & \begin{tabular}{|c}
$35 / 7 /$ \\
20
\end{tabular} & - & - & 0/0/20 & $\begin{array}{c}0 / 0 / \\
20 \\
\end{array}$ & - & - & $10 / 20$ \\
\hline $\begin{array}{l}\text { Солд } \\
\text { место }\end{array}$ & $\begin{array}{c}2.1 / 4 / \\
194\end{array}$ & - & $\begin{array}{l}24.4 / \\
11 / 45\end{array}$ & \begin{tabular}{|c|}
$24.2 /$ \\
$40 /$ \\
165
\end{tabular} & $\begin{array}{l}12.4 / 2 \\
4 / 194\end{array}$ & - & $\begin{array}{c}6.7 / 3 / \\
45\end{array}$ & $\begin{array}{c}14.5 / \\
24 / \\
165\end{array}$ & $\begin{array}{c}0.5 / 1 / \\
194\end{array}$ & - & $\begin{array}{c}0 / 0 / \\
45\end{array}$ & $\begin{array}{c}5.5 / 9 / \\
165\end{array}$ & 4/404 \\
\hline $\begin{array}{l}\text { oe } \\
\text { нние }\end{array}$ & $\begin{array}{c}4.5 / 2 / \\
44\end{array}$ & - & $\begin{array}{c}35.7 / 5 \\
/ 14\end{array}$ & $\begin{array}{c}19.1 / 9 \\
/ 47\end{array}$ & $\begin{array}{c}9.1 / 4 / \\
44\end{array}$ & - & $\begin{array}{c}21.4 / 3 \\
/ 14\end{array}$ & $\begin{array}{c}19.1 / 9 \\
/ 47\end{array}$ & $2.3 / 144$ & - & $0 / 014$ & $\begin{array}{c}4.3 / 2 / \\
47\end{array}$ & $5 / 105$ \\
\hline $\begin{array}{c}\text { Bсе месторож- } \\
\text { дения }\end{array}$ & $6.8 / 29$ & \begin{tabular}{|c|}
$49.1 /$ \\
$57 /$ \\
116
\end{tabular} & $\begin{array}{c}37.3 / \\
28 / 75\end{array}$ & \begin{tabular}{|c}
$24.3 /$ \\
$53 /$ \\
218
\end{tabular} & $\begin{array}{c}8.9 / 39 \\
/ 436\end{array}$ & \begin{tabular}{|c}
$43.1 /$ \\
$53 /$ \\
116
\end{tabular} & $\begin{array}{c}17.3 / \\
13 / 75\end{array}$ & $\begin{array}{c}15.6 / \\
34 / \\
218\end{array}$ & $\begin{array}{c}0.9 / 4 / \\
436\end{array}$ & $\begin{array}{c}35.41 / \\
116\end{array}$ & $\begin{array}{l}9.3 / 7 / \\
75\end{array}$ & $\begin{array}{c}5.1 / 11 \\
/ 218\end{array}$ & $46 / 81$ \\
\hline
\end{tabular}

Примечание: числитель - \%, знаменатель - количество трещиноватых или кавернозных образцов и общее количество проанализированных обр., тире - отсутствие керна, $\mathrm{T}_{1}-\mathrm{T}_{3}-$ отложения турнейского яруса, фм - отложения фаменского яруса.

трещиноватости в структурнотектоническом плане следует считать типичной особенностью карбонатных отложений [1,5]. Связь трещиноватости с наиболее изогнутыми и крутыми элементами антиклинальных и флексурообразных структур отмечена на Карачаганакском месторождении [6]. Наличие ее подтверждается и изменением скоростей акустических волн в плане [1] и оптикополяризационным моделированием распределений упругих деформаций [6]. Во всех исследованиях образование зон разуплотнения наблюдается, как правило, непосредственно над купольными зонами поднятий.

В конкретных скважинах повышенной трещиноватости в большинстве случаев сопутствует и увеличение кавернозности. Это характерно для скв. 19 Кудрявцевского поднятия, для скв. 45 Солдатовского, для скв. 63 Софьинского. Однако в отличие от трещиноватости интенсивное развитие кавернозности свойственно иногда и крыльевым частям поднятий. Одновременное сочетание кавернозных и трещиноватых пород отмечается только в еди- ничных скважинах: в скв.19 на Кудрявцевском поднятии, в скв.45, 91 и 93 на Солдатовском, в скв.63 на Софьинском.

Таким образом, результаты изучения литолого-коллекторских особенностей фаменско-турнейских карбонатных пород сводятся к следующему. В пределах южной платформенной части Пермского Прикамья турнейские отложения сложены преимущественно сгустково-водорослевыми известняками. Среди пористых пород преобладают водорослевые, а среди плотных - сгустковые, водонасыщенные части пластов представлены сгустководетритовыми известняками.

Выражаю благодарность сотрудникам Центра исследования керна и пластовых флюидов (2. Кунгур) за любезно предоставленные материальы.

\section{Библиографический список}

1 Ахметов Р.T. Определение литологического состава и пористости карбонатных пород путем анализа диаграмм комплекса ГИС в масштабе пористости//Тр. БашНИПИнефть. Уфа, 1996. С.37-47. 
2. Багринцева К.И. Особенности формирования и свойства карбонатных коллекторов сложного строения//Особенности строения и формирования сложных коллекторов: сб. науч.тр. ВНИГНИ. 1982. Вып.239. С.3-21.

3. Бетехин А.Г. Минералогия. М.: Госгеолиздат,1950. С.580.

4. Богомолова А.Ф., Глазова В.М. Роль начальной водонасыщенности коллекторов в процессе извлечения нефти//НТО. Сер. Нефтепромысловое дело/ВНИИОЭНГ. М.,1975. 98c.

5. Гудок И.С., Богданович Н.Н., Мартынов В.Г. Определение физических свойств нефте-водосодержащих пород. М.: Недра, 2007. 672c.

6. Добрынин В.М., Вендельштейн Б.Ю., Кожевников Д.А. Петрофизика. М.: Недра, 1981. 234c.
7. Митрофанов В.П. Особенности фильтрационно-ёмкостных свойств карбонатных коллекторов Соликамской депрессии/ВНИИОЭНГ. М., 2001. 113c.

8. Оршинская Н.Н., Бондарчук А.П. Оценка коллекторов в сульфатно-карбонатном комплексе девона в Преддобружии//Нефтяная и газовая промышленность. 1989. №3. С.21-23.

9. Перькова Я.Н. Влияние различных факторов литогенеза на коллекторские свойства карбонатных отложений Астраханского газоконденсатного месторождения. //Особенности строения и формирования сложных коллекторов: сб. науч.тр. ВНИГНИ. Вып.239. С.37-46.

10. Тульбович Б.И. Методы изучения породколлекторов нефти и газа. М.: Недра, 1979. $168 \mathrm{c}$.

\title{
The Lithologic Structural Characteristics of Carbonate Rocks of Famennian- Tournaisian Oil Fields, Southern Perm Prikamye
}

\author{
V.I. Luppov \\ Perm State University, 8 Genkelya Str., Perm 614990, Russia. E-mail: \\ luppov@psu.ru
}

The article presents the study of distribution of the lithological characteristics of carbonate rock of the oil deposits of the southern part of Perm Prikamye. The study revealed that Tournaisian deposits are predominantly composed of the nodular algal limestone. Predominantly algal limestone has the highest permeability and porosity, but predominantly nodular limestone is characterized by lower reservoir properties. Recommendation for usage of results of study for geological and geodynamic modelling of oil reservoirs is given.

Key words: carbonate rocks, lithology, fracture, cavernosity, limestone.

\section{References}

1. Akhmetov R.T. 1996. Opredelenie litologicheskogo sostava i poristosti karbonatnykh porod putem analiza diagramm kompleksa GIS v masshtabe poristosti [Determination of the lithological composition and porosity of carbonate rock using an analysis of borehole logging diagrams in the porosity scale]. In Trudy BashNIPIneft, Ufa, pp.37-47. (in Russian)

2. Bagrintseva K.I. 1982. Osobennosti formirovaniya i svoystva karbonatnykh kollektorov slozhnogo stroeniya [Particularities of for- mation and properties of carbonate reservoirs of complicated structure]. In Osobennosti stroeniya i formirovaniya slozhnykh kollektorov. Sb. nauchn.tr. VNIGNI, 239: 3 21. (in Russian)

3. Betekhin A.G. 1950. Mineralogiya [Mineralogy]. Gosgeolizdat. Moskva, p. 580. (in Russian)

4. Bogomolova A.F., Glazova V.M. 1975. Rol nachalnoy vodonasyshchennosti kollektorov $\mathrm{v}$ processe izvlecheniya nefti [Role of initial water saturation of reservoirs in the process of oil recovery]. NTO, Ser. Neftepromys- 
lovoe delo. VNIIOENG, Moskva, p. 98. (in Russian)

5. Gudok I.S., Bogdanovich N.N., Martinov V.G. 2007. Opredelenie fizicheskikh svoystv nefte-vodosoderzhashchikh porod [Determination of physical properties of the oil-waterbearing rock]. Nedra, Moskva, p. 672. (in Russian)

6. Dobrynin V.M., Vendelshtein B.Yu., Kozhevnikov D.A. 1981. Petrofizika [Petrophysics]. Nedra, Moskva, p. 234. (in Russian)

7. Mitrofanov V.P. 2001. Osobennosti filtratsionno-emkostnykh svoystv karbonatnykh kollektorov Solikamskoy depressii [Particularities of permeability and porosity properties of carbonate reservoirs of Solikamskaya Depression]. VNIIOENG, Moskva, p. 113. (in Russian)

8. Orshinskaya N.N., Bondarchuk A.P. 1989. Otsenka kollektorov v sulfatno-karbonatnom komplekse devona v Preddobruzhii [Reservoirs estimation in the sulfate-carbonate Devonian complex of Pre-Dobrogea]. Neftyanaya i gazovaya promishlennost. 3: 21-23. (in Russian)

9. Perkova Ya.N. 1982. Vliyanie razlichnykh faktorov litogeneza na kollektorskie svoystva karbonatnykh otlozheniy Astrakhanskogo gazokondensatnogo mestorozhdeniya [Influence of different lithogenic factors on the reservoir properties of carbonate rock of the Astrakhan gas-condensate deposit]. Osobennosti stroeniya i formirovaniya slozhnykh kollektorov. Sb. nauchn.tr. VNIGNI. 239: 37-46. (in Russian)

10. Tulbovich B.I. 1979. Metody izucheniya porod-kollektorov nefti i gaza [Methods of study of oil-and-gas reservoirs]. Nedra, Moskva, p. 168. (in Russian) 